Article - Agriculture, Agribusiness and Biotechnology

\title{
Efficacy of Probiotics Supplementation on Growth Performance, Carcass Composition and Hematological Parameters of Cyprinus carpio Fingerlings Fed Corn Gluten Meal-Based Diet
}

\section{Syed Makhdoom Hussain*1}

https://orcid.org/0000-0001-5087-3887

Maria Bashir ${ }^{1}$

https://orcid.org/0000-0003-2063-2489

Shabab Nasir ${ }^{1}$

https://orcid.org/0000-0003-4735-1062

Syed Zakir Hussain Shah ${ }^{2}$

https://orcid.org/0000-0001-5411-4650

Nosheen Aslam ${ }^{3}$

https://orcid.org/0000-0003-2802-0313

\author{
Muhammad Mudassar Shahzad ${ }^{4}$ \\ https://orcid.org/0000-0002-3987-4093 \\ Shimron Ahsan ${ }^{1}$ \\ https://orcid.org/0000-0003-1016-6592
}

\author{
Saba Hanif ${ }^{1}$ \\ https://orcid.org/0000-0001-7583-8885 \\ Majid Hussain 5 \\ https://orcid.org/0000-0001-7548-8117 \\ Nisar Ahmad ${ }^{6}$ \\ https://orcid.org/0000-0002-9326-0965
}

${ }^{1}$ Government College University, Faisalabad, Department of Zoology, Faisalabad, Pakistan; ${ }^{2}$ University of Gujrat, Department of Zoology, Gujrat, Pakistan; ${ }^{3}$ Government College University, Faisalabad, Department of Biochemistry, Faisalabad, Pakistan; ${ }^{4}$ University of Education, Division of Science and Technology, Department of Zoology, Township Lahore, Pakistan; ${ }^{5}$ The University of Lahore, Institute of Molecular Biology and Biotechnology, Lahore, Pakistan; 6University of Education, Department of Zoology, DG Khan Campus, Dera Ghazi Khan, Pakistan.

Editor-in-Chief: Paulo Vitor Farago

Associate Editor: Camila Fediuk de Castro Guedes

Received: 2020.03.31; Accepted: 2021.02.17.

${ }^{*}$ Correspondence: drmakhdoom90@gmail.com; Tel.: +92-32-25595618 (S.M.H.).

\section{HIGHLIGHTS}

- Maximum improvement in growth parameters was observed in Cyprinus carpio fingerlings fed corn gluten meal based diet supplemented with $2 \mathrm{gkg}-1$ level of probiotics supplementation.

- C. carpio fingerlings fed with $2 \mathrm{gkg}-1$ level based diet showed higher values of RBCs, WBCs and platelets whereas $3 \mathrm{gkg}-1$ level showed second higher concentrations of blood parameters.

- Highest carcass composition was noted when fingerlings were fed with $2 \mathrm{gkg}-1$ level while the second higher level of these parameters were noted at $3 \mathrm{gkg}-1$ level based diet.

Abstract: Plant based protein sources are one of the best, cost effective and easily available protein sources being used in fish feed. But due to a lower number of micro-biota in fish gut plant meal based diets cannot be digested and absorbed well in fish body. Probiotics were supplemented at $0,1,2,3,4$ and $5 \mathrm{gkg}^{-1}$ levels in fish feed for formulating one control and five test diets. In this study, three replicates of each treatment 
were used and number of fingerlings was 15 in each replicate. The $C$. carpio (common carp) fingerlings were fed at $5 \%$ of live wet weight on their prescribed diet twice daily. The results revealed that supplementation of probiotics in corn gluten meal based diets significantly $(p<0.05)$ improved growth performance, carcass composition and hematological parameters. Most optimum values of growth performance parameters were noted at $2 \mathrm{gkg}^{-1}$ level of probiotics supplemented diet. $C$. carpio fingerlings fed corn gluten meal based diet supplemented with $2 \mathrm{gkg}^{-1}$ level of probiotics indicated significant $(p<0.05)$ improvements in crude protein $(17 \mathrm{~g})$ crude fat $(9 \mathrm{~g})$ and gross energy $\left(3 \mathrm{kcalg}^{-1}\right)$ whereas higher red blood cells (RBCs), white blood cells (WBCs) and hemoglobin ( $\mathrm{Hb}$ ) was also recorded in fish blood when fed $2 \mathrm{gkg}^{-1}$ probiotics level diet. From these results, it was concluded that $2 \mathrm{gkg}^{-1}$ probiotics supplementation in corn gluten meal based diet is optimum for improving growth performance, body composition and hematology of $C$. carpio fingerlings.

Keywords: probiotics; body composition; hematology; common carp.

\section{INTRODUCTION}

Cyprinus carpio (Common carp) is locally cultured in Asia, Eastern Europe and all around the world. Being a top cultured member of Cyprinids, its annual production range is over 4 million metric tons [17]. It is a freshwater fish and can tolerate a broad range of temperature, $\mathrm{pH}$ and salinity. It is one of the most-willingly farmed species in the world and characterized by the fast growth rate and a good source of protein for humans. It is the third most culturable specie in the world representing $71.9 \%$ of the freshwater species [1]. Aquaculture industry is providing proteinaceous food to the developing and under-developed countries at the rate of $>20$ and $50 \%$, respectively [6]. It is the fastest growing food producing sector to fulfill the requirements of protein [18]. Fishmeal is considered as a superior ingredient in fish feed because it has largest portion of protein content, beneficial lipids, essential amino acids, minerals, vitamins and several growth elements [11]. To provide such nutritious feed to the fish, it is favored by fish farmers, but there are inadequate FM resources [35]. To encounter this problem, fish nutritionists are in continuous struggle to find substitutes of animal protein with novel and low-cost plant proteins. Plant derived proteins fulfill nutritional supplies of fish and simultaneously increase fish culture worldwide [28].

One of the major alternative sources is corn gluten meal (CGM), which have high protein contents (60$70 \%$ on dry matter basis), very low anti-nutritional factors (ANFs) and high ratio of essential amino acids [27]. It is found highly digestible for many fishes $[37,29,22]$. Plant meal-based diets are difficult to digest and absorb in fishes as they have smaller number of micro-biota in their gut $[15,49]$. Probiotics are living microorganisms that may improve the overall fish performance by developing immunity [20] and enhancing digestibility of plant meal-based diets [26]. These micro-organisms help to metabolize the nutrients that cannot be digested by fish without them $[23,45]$. The microbial breakdown of starch, protein, lipids and cellulose helps in fish digestion process $[33,39]$. [51] reported that fish growth performance response depends on type of probiotics used in fish feed. Mostly used microbiota as probiotics in freshwater fish species include Plesiomonas, Aeromonas, members of the family Enterobacteriaceae and Fusobacterium [13]. So, this study was carried out to find the optimum level of probiotics supplementation in CGM based diet for improving the growth performance, hematological parameters and carcass contents of $C$. carpio fingerlings.

\section{MATERIALS AND METHODS}

This experimental trial was conducted in the Fish Nutrition Laboratory, Department of Zoology, Government College University, Faisalabad. C. carpio fingerlings (average weight 7.145 \pm 0.045 ) were purchased for experimental trial from Government Fish Seed Hatchery, Faisalabad and kept in V-shaped water tanks $(70 \mathrm{~L})$ which are specifically designed for collection of feces. Fingerlings were acclimatized for two weeks to adjust with the experimental conditions and fed on basal diet [3]. Before starting the trial, fingerlings were treated with $\mathrm{NaCl}$ solution $\left(5 \mathrm{gL}^{-1}\right)$, to ensure ecto-parasites and fungal free fingerlings [38]. Water quality parameters such as dissolved oxygen (DO), $\mathrm{pH}$, temperature and conductivity were monitored through DO meter (Jenway 970), pH meter (Jenway 3510), thermometer and electrical conductivity (EC) meter (HANNA: HI. 8633) on daily basis. Water quality parameter ranges were maintained as $\mathrm{pH} 7.4-8.6$ dissolved oxygen 5.8-7.3 $\mathrm{mgL}^{-1}$, electrical conductivity $1.30-1.52 \mathrm{dSm}^{-1}$ and temperature $24.9-28.7^{\circ} \mathrm{C}$. Capillary system was used for providing $(24 \mathrm{~h})$ aeration to all experimental tanks. 


\section{Diet formulation and Experimental design}

Corn gluten meal (CGM) having 30\% protein was used to formulate diets by using varying levels of probiotics $($ Ecotec $\AA$ ). (Ecotec contains $2.0 \mathrm{~g}$ of $>8$ billion $\mathrm{CFU})$. The feed ingredients were procured from commercial feed mill and further analyzed for chemical composition ensuing standard methods [5] before formulating the experimental diet (Table 1). The feed ingredients were ground and then sieved to attain required particle size. Feed ingredients were blended as per formulation (Table 2) for 10 minutes to prepare basal diet and kept on adding fish oil gradually. Commercially prepared Ecotec TM (a multi-strain probiotic) was used in this trial that contains 4 billion CFU $\left(4 \times 10^{9} \mathrm{CFUg}^{-1}\right)$ in $1 \mathrm{~g}$ having standardized freeze-dried cultures of Lactobacillus delbrueckii sp, Streptococcus thermophilus STY-31, Bifidobacterium BB-12 and Bulgaricus LBY-27. Probiotics were added at the level of 1, 2, 3, 4 and $5 \mathrm{gkg}^{-1}$ in CGM based basal diet to prepare six test diets. Water (10 to 15\%) was added for the formulation of suitable dough [32]. Lab Extruder (SYSLg30-IV Experimental Extruder) was used to prepare floating pellets (3mm). Prepared diets were dried in an oven and stored at $4^{\circ} \mathrm{C}$ throughout the trial. C. carpio fingerlings were fed with test diets in triplicate twice daily. Fifteen fingerlings were stocked in each replicate. Total 18 water tanks and 270 fingerlings were used to conduct this research work. After two hours of feeding time, the remaining uneaten diet was washed out from the tank and filled with fresh water again. Experimental duration was 70 days.

\section{Chemical analysis of carcass}

After 70 days, four fish were randomly selected for carcass analysis from each replicated tank, dried in oven at $60^{\circ} \mathrm{C}$, ground and were chemically analyzed. Standard methods were used for analyzing the proximate composition of whole-body samples [5]. The moisture content was analyzed by oven drying process $\left(105^{\circ} \mathrm{C}\right.$ for 12 hours), while micro kjeldahl apparatus was used for measuring crude protein $(\mathrm{N} \times 6.25)$. Soxhlet system was used for obtaining ether extracts from petroleum ether. Crude fiber was obtained as a loss on combustion of lipid-free dry residues after digestion with $1.25 \% \mathrm{H}_{2} \mathrm{SO}_{4}$ and $1.25 \% \mathrm{NaOH}$. Crude ash was determined by ignition in electric furnace (Eyela-TMF 3100 ) at $650^{\circ} \mathrm{C}$ for 12 hours. Gross energy was calculated by an adiabatic oxygen bomb calorimeter (Parr Instrument Co., Moline, USA). Total amount of carbohydrates was calculated by following formula:

Total carbohydrates $(\%)=100-($ crude protein $\%+$ crude fat $\%+$ crude fiber $\%+$ ash $\%)$

\section{Hematological study}

For hematological study, fingerlings were anesthetized by using clove oil (Sigma; $60 \mathrm{mg} / \mathrm{L}$ ) by dissolving in ethanol was used for anesthetizing fingerlings [12,36]. A heparinized syringe was used for taking blood samples from the caudal vein of fish. For analyzing hematological indices, blood samples were sent to the Molcare Lab of Biochemistry department, University of Agriculture, Faisalabad, Pakistan. Hematocrit was determined with Micro-hematocrit technique by using capillary tubes [10]. White blood cells (WBCs) and red blood cells (RBCs) were counted with a hemocytometer and approved Neubauer counting chamber [9]. Haemoglobin $(\mathrm{Hb})$ was determined by ensuing the method of [50]. To compute mean corpuscular hemoglobin concentration $(\mathrm{MCHC})$; mean corpuscular hemoglobin $(\mathrm{MCH})$ and mean cell volume (MCV) following formulae were used:

$$
\begin{aligned}
& M C H C=H b / P C V \times 100 \\
& M C V=P C V / R B C \times 10 \\
& M C H=H b / R B C \times 10
\end{aligned}
$$

\section{Growth study}

Growth parameters (weight gain, weight gain\%, FCR and SGR) of $C$. carpio fingerlings were calculated by using standard formulae:

$$
\begin{aligned}
& \text { Weight gain }(\%)=\frac{(\text { Final weight }- \text { Initial weight }) \times 100}{\text { Initial weight }} \text { Feed conversion ratio }(\mathrm{FCR})= \\
& \frac{\text { Total dry feed intake }(\mathrm{g})}{\text { Wet weight gain }(\mathrm{g})} \text { Specific growth rate }(\mathrm{SGR})=\frac{(\text { ln final weight }-\ln \text { initial weight }) \times 100}{\text { No.of days of experiment }}
\end{aligned}
$$




\section{Statistical analysis}

The data of growth, hematology and carcass composition were subjected to one-way analysis of variance ANOVA [43]. Differences among means were compared ensuing Tukey's honesty significant difference test and considered significant as $p<0.05$ [42]. For statistical evaluation, Co-Stat computer software (version 6.303, PMB 320 and Monterey, CA, 93940 USA) was used.

\section{RESULTS}

Highest protein, fat and gross energy contents were observed in fish fed $2 \mathrm{gkg}^{-1}$ level of probiotics supplemented diet while the second highest level of these parameters were recorded at $3 \mathrm{gkg}^{-1}$ in comparison to other groups (Table 3). The lowest protein, fat and gross energy values were noted in fish fed with $5 \mathrm{gkg}^{-}$ ${ }^{1}$ level based diet. Minimum ash contents were observed when fingerlings were fed at $2 \mathrm{gkg}^{-1}$ level of probiotics diet and it was statistically alike to ash contents obtained at $3 \mathrm{gkg}^{-1}$ level. The lowest moisture contents were recorded in fish fed $2 \mathrm{gkg}^{-1}$ followed by $3 \mathrm{gkg}^{-1}$ probiotics supplemented CGM based test diet. Whereas, highest values were found in fish fed $5 \mathrm{gkg}^{-1}$ probiotics and it was statistically alike with the control group.

Highest values of RBCs and WBCs were noted when fish fed on $2 \mathrm{gkg}-1$ probiotic level diet, followed by $3 \mathrm{gkg}-1$ level that were statistically different $(p<0.05)$ from the control group values as shown in figure 1. Lowest values of RBCs and WBCs were found in fingerlings fed at $0 \mathrm{gkg}-1$ probiotics level (control diet). Highest platelets (PLT) and $\mathrm{Hb}$ values were observed in fish fed on $2 \mathrm{gkg}-1$ probiotics level supplemented diet while the second best value was noted at $4 \mathrm{gkg}-1$ level (Table 4$)$. These values were significantly $(p<0.05)$ different in contrast to values found on other levels $(0,1,3$ and $5 \mathrm{gkg}-1$ probiotics). The highest values of packed cell volume (PCV) were found in fingerlings fed diet containing $4 \mathrm{gkg}-1$ probiotics level, while the second best level was $3 \mathrm{gkg}-1$ (Figure 1). The highest values for $\mathrm{MCHC}$ and $\mathrm{MCV}$ were recorded in fingerlings fed diet having $3 \mathrm{gkg}-1$ probiotics level and the lowest values were noted in fish fed at $1 \mathrm{gkg}-1$ probiotics level.
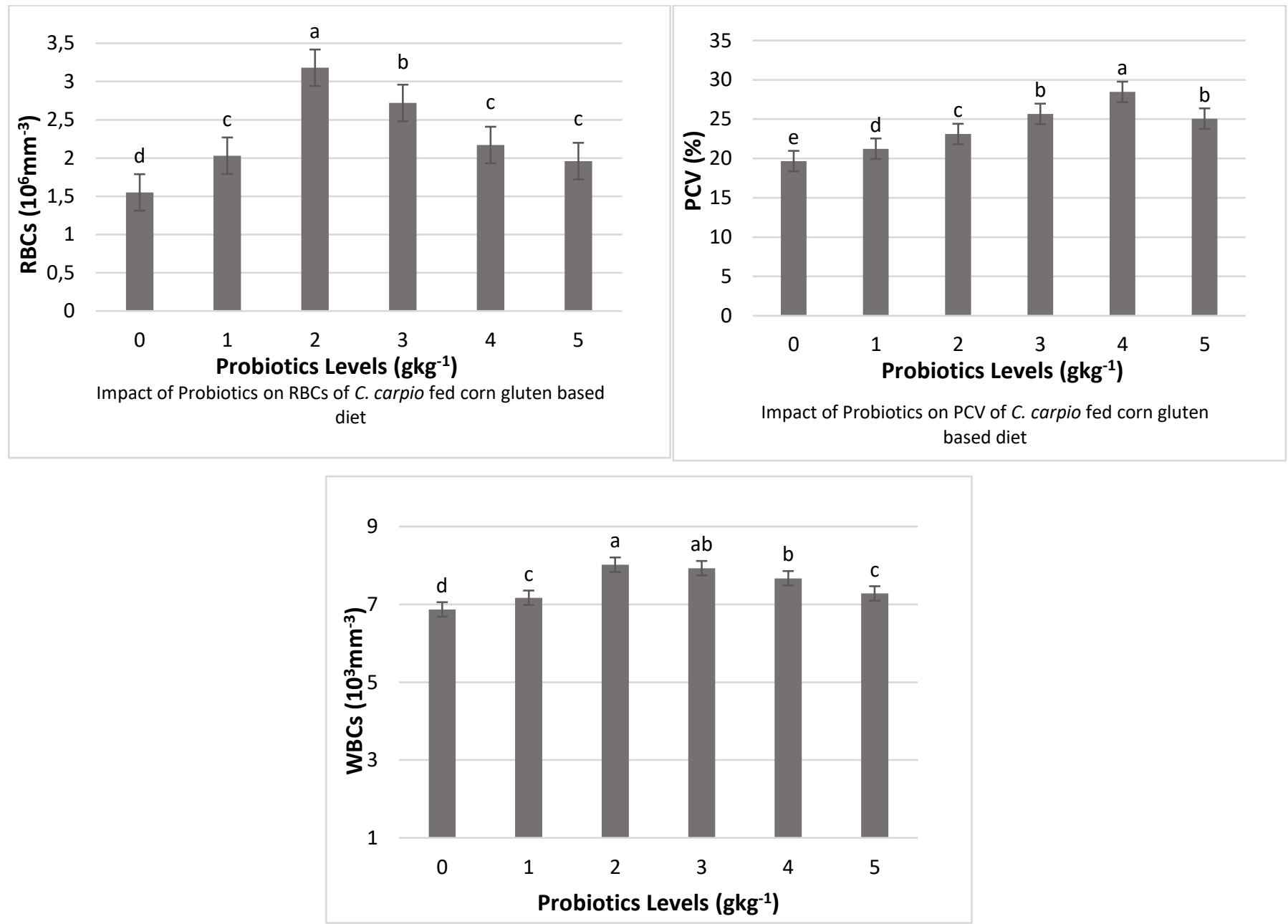

Figure 1. Relationship between probiotics and hematological parameters of $C$. carpio fingerlings fed corn gluten meal based diets 
The maximum weight gain and SGR were recorded in fish fed at $2 \mathrm{gkg}^{-1}$ level of probiotics supplemented CGM based diet followed by fish fed at $1 \mathrm{gkg}^{-1}$ probiotics level (Table 5). These values were statistically different $(p<0.05)$ from control and other experimental groups. Lowest weight gain, weight gain\% and SGR values were recorded at 0 and $5 \mathrm{gkg}^{-1}$ probiotic level. Optimum feed conversion ratio (FCR) and weight gain\% of $C$. carpio fingerlings was observed at $2 \mathrm{gkg}^{-1}$ probiotics supplementation level and it was significantly different $(p<0.05)$ from remaining test and control diets as presented in Figure 2. Second best FCR value was found in fish fed $1 \mathrm{gkg}^{-1}$ probiotics level whereas poor FCR was found in fish fed $5 \mathrm{gkg}^{-1}$ probiotics supplemented diet and it was statistically alike with the values obtained at control diet.

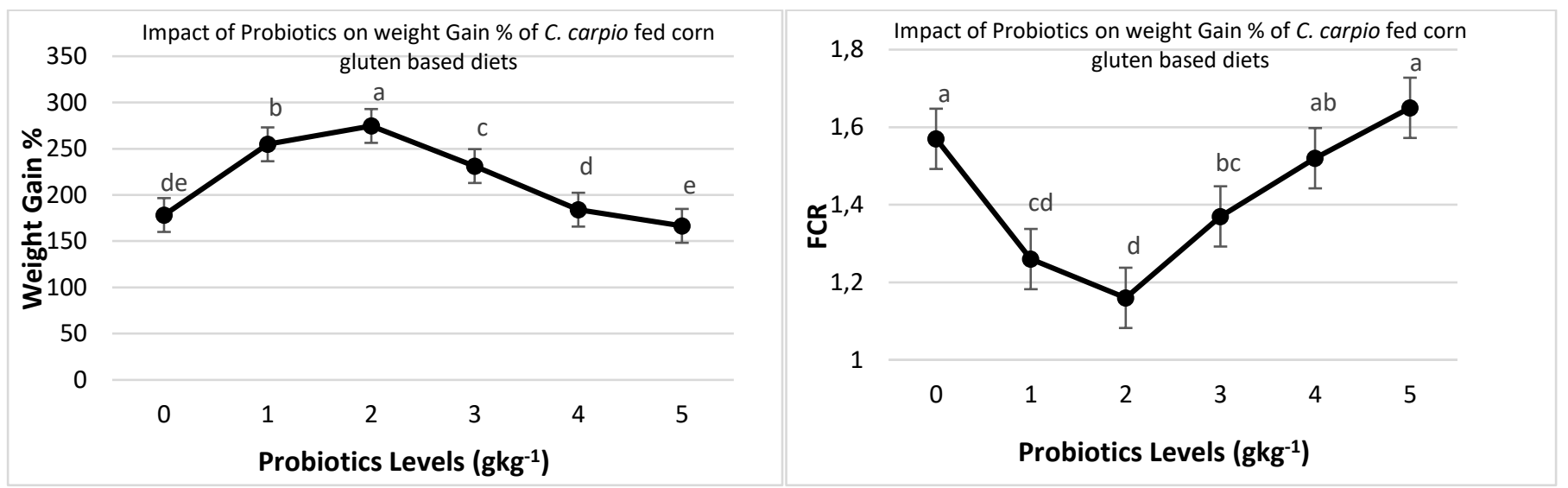

Figure 2. Relationship between probiotics and various growth parameters of $C$. carpio fingerlings fed corn gluten mealbased diets 
Table 1. Ingredient composition (\%) of CGM based diets supplemented with probiotics

\begin{tabular}{|c|c|c|c|c|c|c|}
\hline Ingredients & $\begin{array}{l}\text { Test Diet-I } \\
\text { (Control) }\end{array}$ & Test Diet-II & Test Diet-III & Test Diet-IV & Test Diet-V & Test Diet-VI \\
\hline Probiotics $(\mathrm{g} / \mathrm{kg})$ & 0 & 1 & 2 & 3 & 4 & 5 \\
\hline Corn gluten (30\%) & 50 & 50 & 50 & 50 & 50 & 50 \\
\hline Fish meal & 15 & 15 & 15 & 15 & 15 & 15 \\
\hline Wheat flour & 11 & 10 & 9 & 8 & 7 & 6 \\
\hline Rice polish & 13 & 13 & 13 & 13 & 13 & 13 \\
\hline Fish oil & 7 & 7 & 7 & 7 & 7 & 7 \\
\hline Vitamin Premix* & 1 & 1 & 1 & 1 & 1 & 1 \\
\hline Mineral Premix ${ }^{* *}$ & 1 & 1 & 1 & 1 & 1 & 1 \\
\hline Ascorbic acid & 1 & 1 & 1 & 1 & 1 & 1 \\
\hline Chromic oxide & 1 & 1 & 1 & 1 & 1 & 1 \\
\hline
\end{tabular}

*Each $100 \mathrm{~g}$ of Vitamin premix have Vitamin A 2000,000 IU Vitamin $B_{2} \quad 2000 \mathrm{mg}$

Vitamin $\mathrm{B}_{6} \quad 600 \mathrm{mg}$

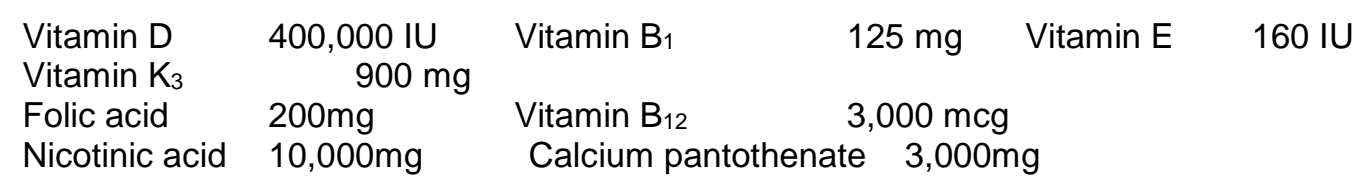

Vitamin C $\quad 1,000 \mathrm{mg} \quad$ Nicotinic acid $10,000 \mathrm{mg} \quad$ Calcium pantothenate $3,000 \mathrm{mg}$

${ }^{* *}$ Each Kg mineral granules have

\begin{tabular}{ll}
\hline $\mathrm{Ca}$ (Calcium) & $155 \mathrm{~g}$ \\
$\mathrm{Cu}$ (Copper) & $600 \mathrm{mg}$ \\
$\mathrm{Fe}$ (Iron) & $1000 \mathrm{mg}$ \\
$\mathrm{Se}$ (Selenium) & $3 \mathrm{mg}$
\end{tabular}

Mn (Manganese)

Mg (Magnesium) I (lodine)

$\mathrm{Na}$ (Sodium)

$\begin{array}{ll}\text { 2000mg } & \text { P (Phosphorous) } 135 \mathrm{~g} \\ 55 \mathrm{gm} & \text { Co (Cobalt) 40mg } \\ 40 \mathrm{mg} \text { Zn (Zinc) } & 3000 \mathrm{mg}\end{array}$


Table 2. Chemical composition (\%) of feed ingredients (Dry matter basis)

\begin{tabular}{|c|c|c|c|c|c|c|c|}
\hline Ingredients & $\begin{array}{c}\text { Dry matter } \\
(\%)\end{array}$ & $\begin{array}{c}\text { Crude Protein } \\
\text { (\%) }\end{array}$ & $\begin{array}{c}\text { Crude Fat } \\
\text { (\%) }\end{array}$ & $\begin{array}{c}\text { Crude Fiber } \\
\text { (\%) }\end{array}$ & Ash (\%) & Carbohydrates (\%) & $\begin{array}{c}\text { Gross Energy } \\
\left(\text { kcalg }^{-1}\right)\end{array}$ \\
\hline Fish meal & 91.63 & 47.25 & 7.43 & 1.12 & 22.56 & 16.97 & 4.67 \\
\hline Corn gluten $30 \%$ & 92.06 & 31.79 & 4.97 & 2.53 & 1.91 & 54.46 & 4.34 \\
\hline Wheat flour & 93.04 & 11.18 & 2.24 & 3.09 & 3.16 & 77.08 & 3.25 \\
\hline Rice polish & 94.86 & 12.62 & 9.98 & 12.87 & 11.29 & 49.65 & 3.59 \\
\hline
\end{tabular}

Table 3. Carcass composition of C. carpio fingerlings fed CGM based test diets supplemented with probiotics

\begin{tabular}{|c|c|c|c|c|c|c|}
\hline Diets & $\begin{array}{c}\text { Probiotics Levels } \\
\left(\mathbf{g k g}^{-1}\right)\end{array}$ & Protein (\%) & Fat (\%) & Ash (\%) & Gross energy & Moisture (\%) \\
\hline $\begin{array}{l}\text { Test Diet-I } \\
\text { (Control) }\end{array}$ & 0 & $11.77 \pm 0.29 d$ & $5.88 \pm 0.15^{d}$ & $7.51 \pm 0.28^{a}$ & $1.64 \pm 0.08^{b c}$ & $71.95 \pm 0.70^{b}$ \\
\hline Test Diet-II & 1 & $13.54 \pm 0.27^{c}$ & $7.32 \pm 0.30^{c}$ & $6.98 \pm 0.17^{a}$ & $1.86 \pm 0.11^{\mathrm{abc}}$ & $69.22 \pm 0.19^{c}$ \\
\hline Test Diet-III & 2 & $16.55 \pm 0.39 a$ & $8.88 \pm 0.23^{a}$ & $4.93 \pm 0.08^{c}$ & $2.20 \pm 0.18^{a}$ & $66.31 \pm 0.55^{d}$ \\
\hline Test Diet-IV & 3 & $15.46 \pm 0.40^{b}$ & $7.99 \pm 0.22^{b}$ & $5.13 \pm 0.18^{c}$ & $1.99 \pm 0.19^{\mathrm{ab}}$ & $68.72 \pm 0.39 c$ \\
\hline Test Diet-V & 4 & $12.93 \pm 0.16^{c}$ & $6.58 \pm 0.18^{c}$ & $5.85 \pm 0.14^{b}$ & $1.65 \pm 0.12^{\mathrm{bc}}$ & $71.83 \pm 0.35^{b}$ \\
\hline Test Diet-VI & 5 & $10.49 \pm 0.21^{\mathrm{e}}$ & $5.55 \pm 0.24^{e}$ & $7.44 \pm 0.27^{a}$ & $1.51 \pm 0.12^{c}$ & $73.66 \pm 0.54^{a}$ \\
\hline
\end{tabular}

All values of means within rows are different significantly $(p<0.05)$

Data values are mean (Mean \pm Standard deviation) of three replicates 
Table 4. Hematological parameters of $C$. carpio fingerlings fed CGM based test diets supplemented with probiotics

\begin{tabular}{|c|c|c|c|c|c|c|}
\hline Diets & $\begin{array}{c}\text { Probiotics } \\
\text { level } \\
\left(\mathrm{gkg}^{-1}\right)\end{array}$ & PLT & $\mathrm{Hb}(\mathrm{g} / 100 \mathrm{~mL})$ & $\mathrm{MCH}(\mathrm{pg})$ & MCHC (\%) & $\operatorname{MCV}(\mathrm{fl})$ \\
\hline Test Diet-I (Control) & 0 & $57.62 \pm 0.31^{\dagger}$ & $6.99 \pm 0.19^{c}$ & $30.40 \pm 0.27^{e}$ & $27.51 \pm 0.22^{c}$ & $97.30 \pm 0.40^{\mathrm{e}}$ \\
\hline Test Diet -II & 1 & $60.27 \pm 0.32^{e}$ & $7.27 \pm 0.21^{c}$ & $31.01 \pm 0.22^{\mathrm{e}}$ & $27.09 \pm 0.20^{c}$ & $101.22 \pm 0.43^{d}$ \\
\hline Test Diet -III & 2 & $68.02 \pm 0.18^{a}$ & $8.85 \pm 0.10^{a}$ & $36.59 \pm 0.17^{d}$ & $31.59 \pm 0.15^{b}$ & $172.59 \pm 0.23^{c}$ \\
\hline Test Diet -IV & 3 & $64.29 \pm 0.29^{c}$ & $8.36 \pm 0.23^{a b}$ & $43.48 \pm 0.23^{c}$ & $33.44 \pm 0.24^{a}$ & $179.69 \pm 0.25^{a}$ \\
\hline Test Diet -V & 4 & $65.96 \pm 0.29 b$ & $8.03 \pm 0.20^{b}$ & $50.66 \pm 0.34^{a}$ & $30.79 \pm 0.20^{b}$ & $171.68 \pm 0.29^{c}$ \\
\hline Test Diet -VI & 5 & $61.14 \pm 0.26^{d}$ & $7.50 \pm 0.17^{c}$ & $49.27 \pm 0.36^{b}$ & $33.03 \pm 0.86^{a}$ & $177.38 \pm 0.63 b$ \\
\hline
\end{tabular}

RBC (Red Blood Cell), WBC (White blood cell), PLT (Platelets), Hb (hemoglobin) (PCV = Packed cell volume, MCHC = Mean corpuscular hemoglobin concentration $\mathrm{MCH}=$ Mean corpuscular hemoglobin, $\mathrm{MCV}=$ Mean corpuscular volume)

All values of means within columns are different significantly $(p<0.05)$

Data values are mean (Mean \pm Standard deviation) of three replicates 
Table 5. Growth performance of $C$. carpio fingerlings fed on CGM based test diets supplemented with probiotics

\begin{tabular}{|c|c|c|c|c|c|c|c|}
\hline Diet levels & $\begin{array}{l}\text { Probiotic } \\
\text { Levels } \\
\left(\mathbf{g k g}^{-1}\right)\end{array}$ & $\begin{array}{l}\text { Initial weight } \\
\text { (g) }\end{array}$ & Final weight (g) & Weight gain (g) & $\begin{array}{l}\text { Weight } \\
\text { gain(fish- } \\
\left.\text { 1ay }^{-1}\right) \mathrm{g}\end{array}$ & $\begin{array}{c}\text { Feed } \\
\text { Intake(fish- } \\
\left.{ }^{1} \text { day }^{-1}\right) \mathrm{g}\end{array}$ & SGR \\
\hline $\begin{array}{l}\text { Test Diet-I } \\
\text { (Control) }\end{array}$ & 0 & $7.12 \pm 0.17$ & $19.81 \pm 0.29^{e}$ & $12.69 \pm 0.13^{d}$ & $0.18 \pm 0.00^{d}$ & $0.28 \pm 0.02^{b}$ & $1.14 \pm 0.01^{d}$ \\
\hline Test Diet-II & 1 & $7.19 \pm 0.19 a$ & $25.49 \pm 0.38^{b}$ & $18.30 \pm 0.20^{b}$ & $0.26 \pm 0.00^{b}$ & $0.33 \pm 0.01^{a}$ & $1.41 \pm 0.01^{b}$ \\
\hline Test Diet -III & 2 & $7.08 \pm 0.20$ & $26.51 \pm 0.29^{a}$ & $19.43 \pm 0.10^{\mathrm{a}}$ & $0.28 \pm 0.00^{\mathrm{a}}$ & $0.32 \pm 0.02^{\mathrm{ab}}$ & $1.47 \pm 0.02^{\mathrm{a}}$ \\
\hline Test Diet -IV & 3 & $7.13 \pm 0.12$ & $23.63 \pm 0.27^{c}$ & $16.49 \pm 0.21^{c}$ & $0.24 \pm 0.00^{c}$ & $0.32 \pm 0.02^{\mathrm{ab}}$ & $1.33 \pm 0.01^{\mathrm{c}}$ \\
\hline Test Diet -V & 4 & $7.15 \pm 0.25$ & $20.32 \pm 0.48^{d}$ & $13.16 \pm 0.23^{d}$ & $0.19 \pm 0.00^{d}$ & $0.29 \pm 0.01^{b}$ & $1.16 \pm 0.01^{d}$ \\
\hline Test Diet -VI & 5 & $7.20 \pm 0.17$ & $19.20 \pm 0.33 d^{e}$ & $12.00 \pm 0.23^{e}$ & $0.17 \pm 0.00^{e}$ & $0.28 \pm 0.01^{b}$ & $1.09 \pm 0.02^{\mathrm{e}}$ \\
\hline
\end{tabular}

All values of means within rows are different significantly $(p<0.05)$

Data values are mean (Mean \pm Standard deviation) of three replicates 


\section{DISCUSSION}

Probiotics are live microorganisms that may be used as dietary supplements to enhance fish performance and immunity. Probiotics impart several benefits to the fish, like improved growth performance, enhanced feed efficiency, boosted immunity status and flourished beneficial intestinal microflora $[2,25,48,47]$. Probiotics produce digestive enzymes that enhance feed digestibility and absorption. The present results showed the highest amount of gross energy (2\%), crude fat $(9 \%)$ and crude protein $(17 \%)$ in whole body when fish fed on $2 \mathrm{~g} \mathrm{~kg}-1$ probiotic supplemented corn gluten meal-based diet while second higher level on these parameters was observed at $3 \mathrm{~g} \mathrm{~kg}-1$ probiotic supplementation. Much like present findings, [14] observed better carcass composition of $\mathrm{C}$. carpio fingerlings fed $0.5 \%$ Saccharomyces cervisiae supplemented soybean meal-based diet. Bisht and coauthors [8] observed lower level of moisture (6.75\%), while higher protein $(30 \%)$ and lipid ( $8 \%$ ) contents in the body of $\mathrm{C}$. carpio fed at $4 \times 108$ cells $100-1 \mathrm{~g} \mathrm{~B}$. subtilis supplemented $(4 \times 106$ cells $100-1 \mathrm{~g})$ rice bran-based diet compared to control group. Suprayudi and coauthors [44] recorded higher protein and lipids absorption in the body of Nile tilapia upon feeding of diet supplemented with 0.25 and $0.5 \mathrm{~g} \mathrm{~kg}-1$ of dietary probiotics. Similarly, Hoyoux and coauthors [23] reported that the diet containing $1 \times 107$ CFUg-1 probiotics for fish showed highest protein, fat and gross energy contents in Nile tilapia. Sahandi and coauthors [40] observed improved apparent digestibility coefficient of crude protein $(68.33 \%)$, crude fat $(9.55 \%)$ and gross energy $(4516.80 \mathrm{cal} / \mathrm{g})$ while using $1 \times 107$ of two probiotics strains (Bifidobacterium). Contrarily, Ayoola and coauthors [7] recorded highest values of moisture (8.20\%), lipid (12.7\%) and ash (4.34\%) at control diet while higher crude protein $(66 \%)$ in Clarias gariepinus group fed $1 \mathrm{~g}$ commercially prepared probiotics (Lactobacillus and Bifidobacterium).

In aquaculture, fish hematology is used in monitoring fish health [24]. In our study fingerlings fed $2 \mathrm{gkg}$ 1 probiotics showed greater value of RBCs $(3.18 \times 106 \mathrm{~mm}-3)$, WBCs $(8.02 \times 103 \mathrm{~mm}-3)$ and PLT (68) whereas the second maximum value was recorded with $3 \mathrm{gkg}-1$ level of probiotic supplementation. It was unclear about the decrement of RBCs and WBCs values in fingerlings fed on higher levels of probiotics supplementation ( 3,4 and $5 \mathrm{~g} / \mathrm{kg}$ ). RBCs numbers over $1.00 \times 10-6 \mathrm{~mm}-3$ in blood is considered high and show higher oxygen carrying capacity with increased metabolic activity [31]. Similar to present results, [30] observed high numbers of RBCs and WBCs at 3\% probiotics supplementation in C. catla fingerlings.

Present results showed that PLT numbers improve with rising probiotics level up to $3 \mathrm{gkg}-1$. Suprayudi and coauthors [44] noticed significantly improved erythrocytes, leucocytes and phagocytic index while feeding $\mathrm{O}$. niloticus upon 0.50 and $1.0 \mathrm{~g}$ of dietary probiotics. Similar to our results, Jafaryan and coauthors [27] studied that addition of probiotics (3×10-4 CFUg-1) in plant meal-based diet showed higher growth performance in Trichopodus trichopterus as compared to other fish groups. Probiotics supplementation at level of 108 and $1010 \mathrm{CFUg}-1$ in Labeo rohita diet improves the growth performance parameters such as growth, feed conversion ratio and SGR [21]. Tan and coauthors [46] reported significant change in weight gain, FCR and feed efficiency of Nile tilapia when fed on $106 \mathrm{CFU} / \mathrm{g}$ of probiotics supplemented diet. Furthermore, Feng and coauthors [19] found out striking increase in weight gain and SGR of common carp while feeding the fish with different strains of probiotics at $(5 \times 108 \mathrm{CFU} / \mathrm{g})$ for 8 weeks. Munir and coauthors [34] ended up with the significant results in terms of FCR (1.24), SGR (1.44) and weight gain (400.45\%) by employing probiotics like Lactobacillus acidophilus in Channa striata. Same findings were also reported by Aly and coauthors [4] in O. niloticus when fed with 10-6 g-1 of probiotics. However, Sha and coauthors observed that FCR and SGR values did not show any improvement when rainbow trout was fed probiotics supplemented diet compared to control group [41]. Similarly, Irianto and coauthors [26] observed nonsignificant differences in the growth performance of rainbow trout in response to probiotics supplemented plant meal-based diet.

\section{CONCLUSION}

Results suggested the usage of $2 \mathrm{gkg}^{-1}$ probiotics as the optimal level for improving the carcass composition, growth performance and hematological parameters of $C$. carpio fingerlings fed CGM based diets.

Funding: This research received no external funding.

Acknowledgments: The authors are gratefully acknowledged to Fish Nutrition Laboratory, Department of Zoology, Government College University, Faisalabad for providing all facilities and equipments to carry out this research work.

Conflicts of Interest: The authors declare no conflict of interest about this research work. 


\section{REFERENCES}

1. Abdel-Tawwab M, Monier MN. Stimulatory effect of dietary taurine on growth performance, digestive enzymes activity, antioxidant capacity, and tolerance of common carp, Cyprinus carpio L., fry to salinity stress. Fish Physiol Biochem. 2018;44(2):639-49.

2. Akhter N, Wu B, Memon AM, Mohsin M. Probiotics and prebiotics associated with aquaculture: a review. Fish Shellfish Immunol.2015;45(2):733-41.

3. Allan GL, Rowland SJ. Development of an experimental diet for silver perch (Bidyanus bidyanus). Austasia Aquacult. 1992;6(3):39-40.

4. Aly SM, Mohamed MF, John G. Effect of probiotics on the survival, growth and challenge infection in Tilapia nilotica (Oreochromis niloticus). Aquacult Res. 2008;39(6):647-56.

5. Association of official analytical chemists - AOAC. Official methods of analysis. 15th ed. Washington DC; 1995.

6. Awad E, Awaad A. Role of medicinal plants on growth performance and immune status in fish. Fish Shellfish Immunol, 2017;67:40-54.

7. Ayoola SO, Ajani EK, Fashae OF. Effect of probiotics (Lactobacillus and Bifidobacterium) on growth performance and hematological profile of Clarias gariepinus juveniles. World J Fish Mar Sci. 2013;5(1):01-08.

8. Bisht A, Singh UP, Pandey NN. Bacillus subtilis as a potent probiotic for enhancing growth in fingerlings of common carp (Cyprinus carpio L.). Indian J Fish. 2012;59(3):103-8.

9. Blaxhall PC, Daisley KW. Routine hematological methods for use with fish blood. J Fish Biol. 1973;5(6):771-81.

10. Brown BA. Hematology: Principles and Procedures. Philadelphia: 1988. 7-122 p.

11. Cho JH, Kim IH. Fish meal-nutritive value. J Anim Physiol Anim Nutr. 2011;95(6):685-92.

12. Coyle SD, Durborow RM, Tidwell JH. Anesthetics in aquaculture. Texas: Southern Regional Aquaculture Center; 2004 Nov.

13. Das S, Mondal K, Haque S. A review on application of probiotic, prebiotic and synbiotic for sustainable development of aquaculture. Growth. 2017;14:5.

14. Dhanaraj M, Haniffa MA, Singh SA, Arockiaraj AJ, Ramakrishanan CM, Seetharaman S, et al. Effect of probiotics on growth performance of koi carp (Cyprinus carpio). J Appl Aquacult. 2010 Sep 8;22(3):202-9.

15. Egerton S, Culloty S, Whooley J, Stanton C, Ross RP. The gut microbiota of marine fish. Front Microbiol. 2018 May 4;9:873.

16. Essa MA, El-Serafy SS, El-Ezabi MM, Daboor SM, Esmael NA, Lall SP. Effect of different dietary probiotics on growth, feed utilization and digestive enzymes activities of Nile tilapia, Oreochromis niloticus. J Arabian Aquacult Soc. 2010;5(2):143-62.

17. FAO, Food and Agriculture Organization of the United Nations. Yearbook of Fishery and Aquaculture Statistics. Rome: Italy; 2018.

18. FAO, Food and Aquaculture Organization. The State of World Fisheries and Aquaculture. Rome:Italy; 2012.197p.

19. Feng J, Chang X, Zhang Y, Yan X, Zhang J, Nie G. Effects of Lactococcus lactis from Cyprinus carpio L. as probiotics on growth performance, innate immune response and disease resistance against Aeromonas hydrophila. Fish Shellfish Immunol, 2019;93:73-81.

20. Gatesoupe FJ. The use of probiotics in aquaculture. Aquacult. 1999 Oct 1;180(1-2):147-65.

21. Giri SS, Sukumaran V, Oviya M. Potential probiotic Lactobacillus plantarum VSG3 improves the growth, immunity, and disease resistance of tropical freshwater fish, Labeo rohita. Fish Shellfish Immunol. 2013 Feb 1;34(2):660-6.

22. Hansen AC, Karlsen $\varnothing$, Rosenlund G, Rimbach M, Hemre GI. Dietary plant protein utilization in Atlantic cod, Gadus morhua L. Aquacult Nutr. 2007 Jun;13(3):200-15.

23. Hoyoux C, Zbinden M, Samadi S, Gaill F, Compère P. Wood-based diet and gut microflora of a galatheid crab associated with Pacific deep-sea wood falls. Mar Biol. 2009 Nov 1;156(12):2421-39.

24. Hrubec TC, Cardinale JL, Smith SA. Hematology and plasma chemistry reference intervals for cultured tilapia (Oreochromis hybrid). Vet Clin path. 2000 Mar;29(1):7-12.

25. Huynh TG, Shiu YL, Nguyen TP, Truong QP, Chen JC, Liu CH. Current applications, selection, and possible mechanisms of actions of synbiotics in improving the growth and health status in aquaculture: a review. Fish Shellfish Immunol. 2017;64:367-82.

26. Irianto A, Austin B. Use of probiotics to control furunculosis in rainbow trout, Oncorhynchus mykiss (Walbaum). J Fish Dis. 2002 Jun;25(6):333-42.

27. Jafaryan H, Sahandi J, Bagheri Dorbadam J. Growth and length-weight relationship of Trichopodus trichopterus (pallas, 1770) fed a supplemented diet with different concentrations of probiotic. Croatian J Fish. 2014 Sep 25;72(3):118-22.

28. Kaur R, Shah TK. A review on role of plant waste products on fish growth, health and production. J Entomol Zool Stud. 2017;5:583-9. 
29. Köprücü K, Özdemir Y. Apparent digestibility of selected feed ingredients for Nile tilapia (Oreochromis niloticus). Aquacult. 2005 Nov 14;250(1-2):308-16.

30. Krishnaveni R, Palanivelu K, Velavan S. Effects of probiotics and Spirulina supplementation on haematoimmunological function of Catla catla. Int J Res Fish Aquacult. 2013;3(4):176-81.

31. Lenfant C, Johansen K. Gas exchange in gill, skin and lung breathing. Respir physiol. 1972 Mar 1;14(1-2):211-8.

32. Lovell T. Nutrition and feeding of fish. New York: 1989. 260 p.

33. Mondal S, Roy T, Ray AK. Characterization and identification of enzyme-producing bacteria isolated from the digestive tract of bata, Labeo bata. J World Aquacult Soc. 2010 Jun;41(3):369-77.

34. Munir MB, Hashim R, Chai YH, Marsh TL, Nor SAM. Dietary prebiotics and probiotics influence growth performance, nutrient digestibility and the expression of immune regulatory genes in snakehead (Channa striata) fingerlings. Aquaculture. 2016;460:59-68.

35. Oniszczuk T, Oniszczuk A, Gondek E, Guz L, Puk K, Kocira A, et al. Active polyphenolic compounds, nutrient contents and antioxidant capacity of extruded fish feed containing purple coneflower (Echinacea purpurea (L.) Moench.). Saudi J Biol. Sci. 2019;26(1):24-30.

36. Peake S. Sodium bicarbonate and clove oil as potential anesthetics for nonsalmonid fishes. North Am J Fish Manage. 1998 Nov;18(4):919-24.

37. Pereira TG, Oliva-Teles A. Evaluation of corn gluten meal as a protein source in diets for gilthead sea bream (Sparus aurata L.) juveniles. Aquacult Res. 2003 Nov;34(13):1111-7.

38. Rowland SJ. Diseases of Australian native freshwater fishes with particular emphasis on the ectoparasitic and fungal diseases of Murray cod (Maccullochella peeli), golden perch (Macquaria ambigua) and silver perch (Bidyanus bidyanus). Dept. of Agriculture, New South Wales; 1991.

39. Saha S, Roy RN, Sen SK, Ray AK. Characterization of cellulase-producing bacteria from the digestive tract of tilapia, Oreochromis mossambica (Peters) and grass carp, Ctenopharyngodon idella (Valenciennes). Aquacult Res. 2006 Mar;37(4):380-8.

40. Sahandi J, Jafaryan H, Soltani M, Ebrahimi $P$. The use of two Bifidobacterium strains enhanced growth performance and nutrient utilization of Rainbow Trout (Oncorhynchus mykiss) fry. Probiotics Antimicrob Proteins. 2019;11(3):966-72.

41. Sha A, Jafaryan H, Farahi A, Ahmadvand S. Effect of frozen Daphnia magna diet mixed with probiotic Protexin on growth and survival of rainbow trout (Oncorhynchus mykiss) fry reared under controlled conditions. Online J Anim Feed Res. 2012;2(1):34-9.

42. Snedecor GW, Cochran WG. Statistical methods, $8^{\text {th }}$ ed. Ames: lowa State Univ. Press lowa. 1989.

43. Steel RGD, Torrie JH, Dickey DA. Principles and procedures of statistics. $3^{\text {rd }}$ ed. New York: McGraw Hill International Book Co Inc; USA. 1997. p. 336-352.

44. Suprayudi MA, Maeda M, Hidayatullah H, Widanarni W, Setiawati M, Ekasari J. The positive contributions of PowerLac ${ }^{\mathrm{TM}}$ supplementation to the production performance, feed utilization and disease resistance of Nile tilapia Oreochromis niloticus (L.). Aquacult Res. 2017;48(5):2145-56.

45. Suzer C, Kamaci HO, Coban D, Saka Ş, Firat K, Özkara B, Özkara A. Digestive enzyme activity of the red porgy (Pagrus pagrus, L.) during larval development under culture conditions. Aquacult Res. 2007 Dec;38(16):1778-85.

46. Tan HY, Chen SW, Hu SY. Improvements in the growth performance, immunity, disease resistance, and gut microbiota by the probiotic Rummeliibacillus stabekisii in Nile tilapia (Oreochromis niloticus). Fish Shellfish Immunol. 2019;92:265-75.

47. Van HN. Research findings from the use of probiotics in tilapia aquaculture: a review. Fish Shellfish Immunol. 2015;45(2):592-7.

Wang A, Ran C, Wang Y, Zhang Z, Ding Q, Yang Y, et al. Use of probiotics in aquaculture of China-a review of the past decade. Fish Shellfish Immunol. 2019;86:734-55.

48. Wang AR, Ran C, Ringø E, Zhou ZG. Progress in fish gastrointestinal microbiota research. Rev Aquacult. 2018 Aug;10(3):626-40.

49. Wedemeyer GA, Yasutake W. Clinical methods for the assessment of the effects of environmental stress on fish health. Department of the Interior, Fish and Wildlife Service; 1977.

50. Zhou QC, Tan BP, Mai KS, Liu YJ. Apparent digestibility of selected feed ingredients for juvenile cobia Rachycentron canadum. Aquaculture. 2004 Nov 26;241(1-4):441-51.

(C) 2021 by the authors. Submitted for possible open access publication under the terms and conditions of the Creative Commons Attribution (CC BY NC) license (https://creativecommons.org/licenses/by-nc/4.0/). 